\title{
On the Reactivity of $\alpha$-(Triphenylphosphoranylidene)-benzylphenylketene with Nitrogen Compounds. Synthetic and Mechanistic Implications
}

\author{
Silvio Cunha*,\# and Albert Kascheres \\ Instituto de Química, Universidade Estadual de Campinas, CP 6154, 13083-970 Campinas-SP, Brazil

\begin{abstract}
A reatividade do ilídeo de fósforo estabilizado derivado da difenilciclopropenona, o $\alpha$ (trifenilfosforanilideno)-benzilfenilceteno, frente a compostos nitrogenados polifuncionalizados foi investigada. Em particular, a reação do $\alpha$-(trifenilfosforanilideno)-benzilfenilceteno com o azodicarboxilato de etila pode se constituir como um novo método de síntese de $\mathrm{N}$-acil-carbamatos densamente substituidos.
\end{abstract}

The reactivity of $\alpha$-(triphenylphosphoranylidene)-benzylphenylketene, a stabilized phosphorus ylide derived from diphenylcyclopropenone, toward nitrogen compounds was investigated. Particularly, the reaction of diethyl azodicarboxylate with $\alpha$-(triphenylphosphoranylidene)benzylphenylketene provides a new route to polysubstituted $N$-acyl carbamates.

Keywords: $\alpha$-(triphenylphosphoranylidene)-benzylphenylketene, phosphorus ylides, diphenylcyclopropenone, acyl carbamate

\section{Introduction}

While the reactivity of diphenylcyclopropenone (1) with nucleophiles has been well documented, ${ }^{1}$ studies of the behavior of its derivative $\alpha$-(Triphenylphosphoranylidene)-benzylphenylketene (2, $\alpha$-TPBPK) with such reagents are scarce. ${ }^{2}$ Otherwise, phosphorus ylides have been intensively used in organic synthesis, mainly in olefination reactions. ${ }^{3}$ Stabilized triphenylphosphonium ylides have attracted attention and new methods of preparation, ${ }^{4}$ their behavior under pyrolysis conditions ${ }^{5}$ and structural elucidation ${ }^{6}$ still demand investigation. When carrying out a transformation with stabilized triphenylphosphonium ylides their nucleophilicity has been the prime consideration. ${ }^{?}$

Recently, we reported the study of the reaction of triphenylphosphoranylidenesuccinic anhydride with a broad spectrum of nitrogen nucleophiles and a new method of synthesis of phosphonioum salts was described. ${ }^{8}$ Our continued interest in the chemistry of cyclopropenones and their derivatives ${ }^{1}$ as well as in the reactivity of phosphorus ylides stabilized by electrophilic functions ${ }^{8}$ prompted us to study the behavior of $\alpha$-TPBPK toward nitrogen

\footnotetext{
*e-mail: silviodc@ufba.br

* Present address: Instituto de Química, Universidade Federal da
} Bahia, Campus de Ondina, 40170-290 Salvador-BA, Brazil compounds. In this work we present our results concerning the reactivity of $\alpha$-TPBPK with such derivatives with emphasis on synthetic and mechanistic implications.

\section{Results and Discussion}

The ambiphilic $\alpha$-TPBPK 2 is readily prepared by the reaction of diphenylcyclopropenone with triphenylphosphine. As expected, this solid is stable only under anhydrous conditions, but alternatively it can be generated in situ. ${ }^{2}$ Thus, equimolar amounts of triphenylphosphine and diphenylcyclopropenone (1) were reacted under inert atmosphere and then the nucleophile was introduced (see Experimental). Among the broad spectrum of nitrogen nucleophiles available, we selected ones whose reactivity toward diphenylcyclopropenone was known. Thus, we began our study with 2-amino-4-methylpyridine $\mathbf{3},{ }^{9}$ pyridinium $N$-imine $4^{10}$ and $N$-benzoylacetamidine $\mathbf{5}^{1}$ (examples of reactivity towards $\mathbf{1}$ are shown in Scheme 1).

$\alpha$-TPBPK reacted with 2-amino-4-methylpyridine (3) to afford a crystalline solid along with almost quantitative recovery of triphenylphosphine. Although the IR spectrum of the product suggested the presence of amide $\mathrm{NH}$ and $\mathrm{C}=\mathrm{O}$ groups, and proton NMR integration indicated that this material was a 1:1 adduct, the chemical shifts of the pyridinic ring ruled out the formation of $6\left(\delta \mathrm{H}_{3} 6.15, \delta \mathrm{H}_{5}\right.$ 6.37 and $\delta \mathrm{H}_{6} 7.60$, and $8.30,6.80$ and 8.10 for $\mathbf{6}$, 


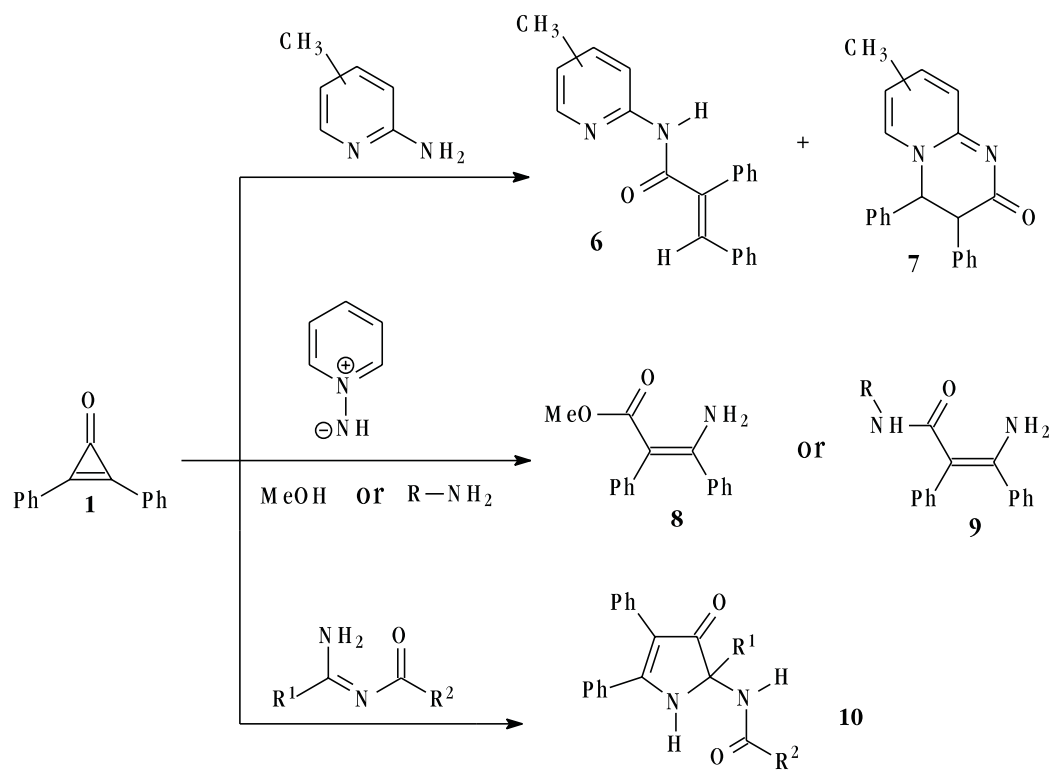

Scheme 1.

respectively ${ }^{9}$ ). Additionally, the NMR spectrum contained a low field $\mathrm{N}-\mathrm{H}$ proton $\left(\delta 10.20, \mathrm{D}_{2} \mathrm{O}\right.$ exchangeable) as a broad signal and an olefinic proton as a sharp singlet at $\delta$ 7.82 , indicating a cis relationship of the phenyl groups as in 6, where this absorption appears at $\delta 8.0 .^{9}$ To accommodate these spectral features structure $\mathbf{1 1}$ was proposed (Scheme 2). Also, the hydrogen chemical shifts mentioned above for the nitrogen-containing ring of $\mathbf{1 1}$ with an exocyclic carbon-nitrogen double bond are in agreement with a model compound previously reported by us (11a, Scheme 2), whose X-ray structure was obtained. ${ }^{11}$ It should be pointed out that $\mathbf{1 1}$ is not converted into 6 under reflux in chloroform or nitromethane. Under basic conditions $\left(\mathrm{K}_{2} \mathrm{CO}_{3}\right), \alpha$-phenylcinnamic acid is the sole isolated compound.

When $\alpha$-TPBPK was reacted with pyridinium $N$-imine (4), generated in situ by reaction of $\mathrm{N}$-aminopyridinium iodide ${ }^{12}$ with $\mathrm{K}_{2} \mathrm{CO}_{3}$, compound $\mathbf{1 2}$ was isolated in modest yield (Scheme 2). The pyridinium $\operatorname{ring}^{13}$ and the $N-\alpha$ phenylcinnamoyl moiety ${ }^{9}$ in $\mathbf{1 2}$ could be defined by comparison with analogues described in the literature. We next studied the reaction of $\mathbf{2}$ with $\mathrm{N}$-benzoylacetamidine (5). In this case, a mixture of products 13-15 was obtained in contrast to the reaction of this nucleophile ${ }^{1}$ with $\mathbf{1}$. As in the reaction of $\mathbf{2}$ with $\mathbf{3}$, triphenylphosphine was recovered in the reaction of $\mathbf{2}$ with $\mathbf{4}$ and $\mathbf{5}$. From a mechanistic viewpoint, the formation of 11-15 may be visualized as occurring through attack of the nitrogen nucleophile at the electrophilic carbon of the ketene portion of $\mathbf{2}$, followed by triphenylphosphine elimination and proton transfer (Scheme 3 ).
To provide insight into the behavior of $\alpha$-TPBPK toward nitrogen compounds without transferable hydrogen, $\mathbf{2}$ was treated with azobenzene and $N$-( $p$-methoxyphenyl)benzaldimine, but only complex mixtures were formed. However, with diethyl azodicarboxylate 16 a clean reaction took place, wherein the $N$-acyl carbamate (17) was formed in excellent yield. This is a very interesting result since densely substituted $\mathrm{N}$-acyl carbamates are versatile intermediates in the synthesis of nucleoside analogues and their preparation is not a trivial task. ${ }^{14}$

Contrary to the other reactions described above, triphenylphosphine oxide was the co-product, and the phenyl groups are positioned trans in $\mathbf{1 7}$, as indicated by the chemical shift of the olefinic hydrogen as a sharp singlet at $\delta 7.20$ (in $\mathbf{6},{ }^{9} \mathbf{1 1}$ and $\mathbf{1 2}$ the phenyl groups are positioned cis and the olefinic proton appears at $\delta 8.0, \delta$ 7.82 and $\delta 7.82$, respectively). However, the formation of 17 is not well understood and its mechanism is under study.

The results of the present work, together with those obtained previously with triphenylphosphoranylidenesuccinic anhydride, ${ }^{8}$ provide an interesting spectrum of reactivity for phosphorus ylides stabilized by electrophilic functions, and also expand the frontiers of applications of cyclopropenone derivatives in synthesis. Particularly, the formation of $\mathbf{1 7}$ provides a new route to polysubstituted $N$-acyl carbamates. Studies involving the preparation of unsymmetrical cyclopropenones and their reactions with diethyl azodicarboxylate are under investigation to establish the mechanism, scope and limitations of this new synthetic protocol. 


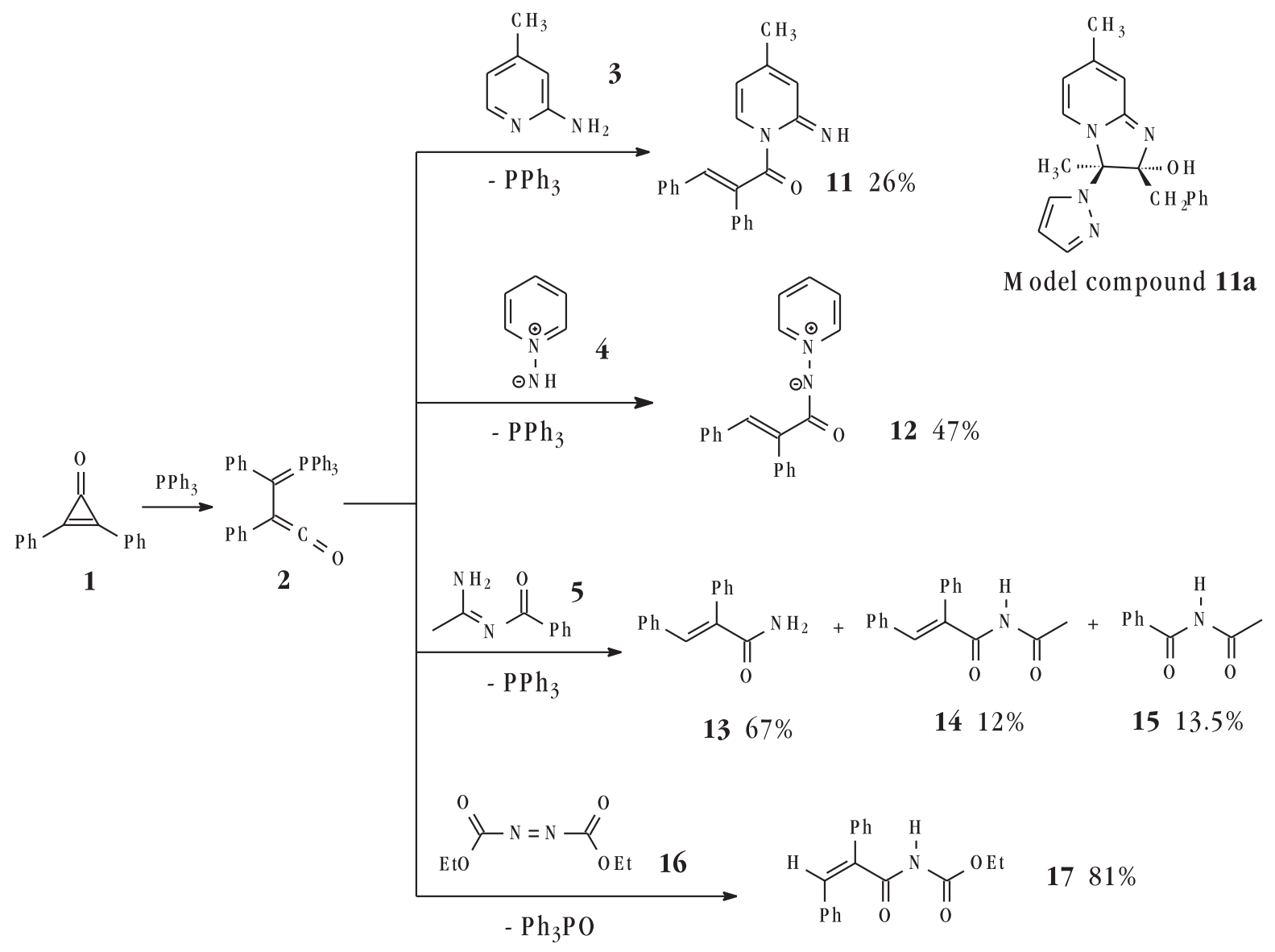

Scheme 2.

\section{Experimental}

Melting points were measured on a Hoover-Unimelt apparatus and are uncorrected. Infrared spectra were recorded as $\mathrm{KBr}$ discs on a Perkin Elmer FT-IR 1600 instrument. NMR spectra were obtained for ${ }^{1} \mathrm{H}$ at $300 \mathrm{MHz}$ and for ${ }^{13} \mathrm{C}$ at 75 $\mathrm{MHz}$ using a Varian Gemini 300 or a Bruker AC300P spectrometer. Unless otherwise stated, all spectra were run in $\mathrm{CDCl}_{3}$ solutions. Chemical shifts are reported in $\delta(\mathrm{ppm})$ units downfield from reference. Elemental analyses were performed on a Perkin Elmer 2401 Elemental Analysis by Instituto de Química, Universidade Estadual de Campinas,
Brazil. $N$-aminopyridinium iodide, ${ }^{12} N$-benzoylacetamidine $^{15}$ and diphenylcyclopropenone ${ }^{16}$ were prepared according to known procedures. All reactions were performed under a positive pressure of argon with oven-dried glassware $\left(120{ }^{\circ} \mathrm{C}\right)$. Benzene and $\mathrm{CH}_{2} \mathrm{Cl}_{2}$ were distilled from $\mathrm{Na}$ benzophenone and $\mathrm{CaH}_{2}$, respectively.

Reaction of $\alpha$-TPBPK with 2-amino-4-methylpyridine (3). A solution of $265.7 \mathrm{mg}(1.3 \mathrm{mmol})$ of diphenylcyclopropenone (1) and $345.6 \mathrm{mg}(1.3 \mathrm{mmol})$ of triphenylphosphine in $5.0 \mathrm{~cm}^{3}$ of benzene in a two-necked roundbottom flask was left at room temperature with stirring for<smiles>O=C=C(C(=P)c1ccccc1)c1ccccc1</smiles><smiles>O=C1NCCCC1c1ccccc1</smiles><smiles>NC(=O)/C(=C/c1ccccc1)c1ccccc1</smiles> 
$2 \mathrm{~h}$. To the orange solution was added via syringe 141.3 $\mathrm{mg}(1.3 \mathrm{mmol})$ of 2-amino-4-methylpyridine (3) in $3.0 \mathrm{~cm}^{3}$ of benzene. The solution turned yellow and was left stirring for $18 \mathrm{~h}$, after which time the solvent was removed under reduced pressure. The residual solid was triturated with ethyl ether yielding $105.8 \mathrm{mg}$ (26\%) of $\mathbf{1 1}$ as a colorless solid, mp 131-132 ${ }^{\circ} \mathrm{C}$. IR (KBr): $v_{\max } / \mathrm{cm}^{-1} 3349,1676,1646$. ${ }^{1} \mathrm{H}$ NMR: 2.19 (s, 3H), 6.15 (s, 1H), $6.37\left(\mathrm{~d},{ }^{3} \mathrm{~J} 6 \mathrm{~Hz}, 1 \mathrm{H}\right)$, 7.01-7.09 (m, 2H); 7.10-7.14 (m, 3H); 7.26-7.37 (m, 5H), $7.60\left(\mathrm{~d},{ }^{3} \mathrm{~J} 6 \mathrm{~Hz}, 1 \mathrm{H}\right), 7.82(\mathrm{~s}, 1 \mathrm{H}), 10.20(\mathrm{~b}, 1 \mathrm{H}) .{ }^{13} \mathrm{C}$ NMR: $21.5\left(\mathrm{CH}_{3}\right), 111.4(\mathrm{CH}), 113.7(\mathrm{CH}), 127.1(\mathrm{CH}), 128.0$ $(\mathrm{CH}), 128.4(\mathrm{CH}), 129.8(\mathrm{CH}), 130.3(\mathrm{CH}), 135.8(\mathrm{C}), 137.2$ $(\mathrm{CH}), 137.4(\mathrm{C}), 138.3(\mathrm{C}), 138.8(\mathrm{CH}), 152.9(\mathrm{C}), 156.6$ (C), 174.3 (C). Anal. Calcd. for $\mathrm{C}_{21} \mathrm{H}_{18} \mathrm{~N}_{2} \mathrm{O}: \mathrm{C}, 80.25 \%$; H, 5.73\%; N, 8.92\%. Found: C, $80.35 \%$; H, 5.71\%; N, $8.99 \%$.

Reaction of $\alpha$-TPBPK with pyridinium $N$-imine (4). A solution of $410.0 \mathrm{mg}(2.0 \mathrm{mmol})$ of diphenylcyclopropenone (1) and $533.5 \mathrm{mg}(2.0 \mathrm{mmol})$ of triphenylphosphine in 8.0 $\mathrm{cm}^{3}$ of $\mathrm{CH}_{2} \mathrm{Cl}_{2}$ in a two-necked round-bottom flask was left at room temperature with stirring for $1.5 \mathrm{~h}$. To the orange solution was added successively $284.0 \mathrm{mg}(2.1 \mathrm{mmol})$ of anhydrous $\mathrm{K}_{2} \mathrm{CO}_{3}$ and $222.0 \mathrm{mg}(1.0 \mathrm{mmol})$ of $\mathrm{N}$ aminopyridinium iodine. The reaction mixture was left stirring for $15 \mathrm{~h}$, after which time was filtered and the solvent was removed under reduced pressure. The residue was triturated with petroleum ether and them purified by column chromatography (Florisil ${ }^{\circledast}$, chloroform as eluent) to afford a solid witch was recrystallized from $\mathrm{CH}_{2} \mathrm{Cl}_{2}$ /petroleum ether yielding $141.9 \mathrm{mg}$ (47\%) of $\mathbf{1 2}$ as a pale yellow solid, $\mathrm{mp}$ 154$156{ }^{\circ} \mathrm{C}$. IR (KBr): $v_{\max } / \mathrm{cm}^{-1} 1638,1557,1470,1301 .{ }^{1} \mathrm{H}$ NMR: $7.02(\mathrm{~m}, 2 \mathrm{H}), 7.11(\mathrm{~m}, 3 \mathrm{H}), 7.26-7.36(\mathrm{~m}, 5 \mathrm{H}), 7.60(\mathrm{t}$, $\left.{ }^{3} J 7.1 \mathrm{~Hz}, 2 \mathrm{H}\right), 7.82(\mathrm{~s}, 1 \mathrm{H}), 7.86\left(\mathrm{t},{ }^{3} J 7.1 \mathrm{~Hz}, 1 \mathrm{H}\right), 8.63\left(\mathrm{~d},{ }^{3} \mathrm{~J}\right.$ 5.6Hz, 2H). ${ }^{13} \mathrm{C} \mathrm{NMR:} 125.7(\mathrm{CH}), 126.8(\mathrm{CH}), 127.4(\mathrm{CH})$, $127.8(\mathrm{CH}), 128.2(\mathrm{CH}), 129.9(\mathrm{CH}), 130.1(\mathrm{CH}), 134.1(\mathrm{CH})$, $136.3(\mathrm{C}), 137.0(\mathrm{CH}), 138.7(\mathrm{C}), 139.1(\mathrm{C}), 143.4(\mathrm{CH})$, 172.4 (C). Anal. Calcd. for $\mathrm{C}_{20} \mathrm{H}_{16} \mathrm{~N}_{2} \mathrm{O}: \mathrm{C}, 80.00 \% ; \mathrm{H}, 5.33 \%$; N, 9.33\%. Found: C, 79.79\%; H, 5.20\%; N, 9.21\%.

Reaction of $\alpha$-TPBPK with $N$-benzoylacetamidine (5). A solution of $105.0 \mathrm{mg}(0.5 \mathrm{mmol})$ of diphenylcyclopropenone (1) and $134.3 \mathrm{mg}(0.5 \mathrm{mmol})$ of triphenylphosphine in $8.0 \mathrm{~cm}^{3}$ of benzene in a two-necked roundbottom flask was left at room temperature with stirring for $2 \mathrm{~h}$. To the orange solution was added $83.2 \mathrm{mg}(0.5 \mathrm{mmol})$ of $\mathrm{N}$-benzoylacetamidine (5). The solution turned yellow and was left stirring for $24 \mathrm{~h}$. After this time the solvent was removed under reduced pressure and the residue was purified by column chromatography (Florisil ${ }^{\circledR}$ ) affording $15.7 \mathrm{mg}$ (12\%) of $\mathbf{1 4}$ (benzene/ethyl acetate $5 \%$ ), $28.1 \mathrm{mg}$ (13.5\%) of $\mathbf{1 5}^{17}$ (benzene/ethyl acetate 5\%) and $76.5 \mathrm{mg}$ (67\%) of $\alpha$-phenylcinnamamide (13) ${ }^{18}$ (benzene/ethyl acetate 10\%). 14: IR (KBr): $v_{\max } / \mathrm{cm}^{-1} 3274,1706,1690$, 1610. ${ }^{1} \mathrm{H}$ NMR: 2.57 (s, 3H), 7.01 (d, $\left.{ }^{3} J 7.3 \mathrm{~Hz}, 2 \mathrm{H}\right), 7.15-$ 7.37 (m, 5H), 7.49-7.52 (m, 3H), $7.83(\mathrm{sl}, 1 \mathrm{H}), 7.96(\mathrm{~s}, 1 \mathrm{H})$. ${ }^{13} \mathrm{C} \mathrm{NMR:} 25.4\left(\mathrm{CH}_{3}\right), 128.6(\mathrm{CH}), 129.6(\mathrm{CH}), 129.8(\mathrm{CH})$, $129.9(\mathrm{CH}), 130.4(\mathrm{CH}), 131.0(\mathrm{CH}), 133.5(\mathrm{C}), 134.7(\mathrm{C})$, $134.9(\mathrm{C}), 141.3(\mathrm{CH}), 165.7(\mathrm{C}), 173.3(\mathrm{C})$.

Reaction of a-TPBPK with diethyl azodicarboxylate (16). A solution of $314.4 \mathrm{mg}(1.5 \mathrm{mmol})$ of diphenylcyclopropenone (1) and $396.8 \mathrm{mg}$ (1.5 mmol) of triphenylphosphine in $5.0 \mathrm{~cm}^{3}$ of benzene in a two-necked roundbottom flask was left at room temperature with stirring for $2 \mathrm{~h}$. To the orange solution was added via syringe $170.7 \mathrm{mg}(1.0 \mathrm{mmol})$ of diethyl azodicarboxylate (16) in $4.0 \mathrm{~cm}^{3}$ of benzene. The solution turned yellow and was left stirring for $18 \mathrm{~h}$. After this time the solvent was removed under reduced pressure and the residue was triturated with petroleum ether. Purification by column chromatography (Florisil ${ }^{\circledast}$, hexane/ethyl acetate $30 \%$ ) afforded $233.6 \mathrm{mg}$ (81\%) of $\mathbf{1 7}$ as a colorless solid, mp $154-156^{\circ} \mathrm{C}$. IR (KBr): $v_{\max } / \mathrm{cm}^{-1} 1762,1705 .{ }^{1} \mathrm{H}$ NMR $\left(\mathrm{CCl}_{4}\right): 1.18\left(\mathrm{t},{ }^{3} \mathrm{~J} 7.1 \mathrm{~Hz}\right.$, $3 \mathrm{H}), 4.14\left(\mathrm{q},{ }^{3} \mathrm{~J} 7.1 \mathrm{~Hz}, 2 \mathrm{H}\right), 7.09(\mathrm{~m}, 5 \mathrm{H}), 7.20(\mathrm{~s}, 1 \mathrm{H}), 7.21-$ $7.25(\mathrm{~m}, 3 \mathrm{H}), 7.35-7.39$ (m, 2H). ${ }^{13} \mathrm{C}$ NMR $\left(\mathrm{CCl}_{4}\right)$ : 14.0 $\left(\mathrm{CH}_{3}\right), 63.2\left(\mathrm{CH}_{2}\right), 127.7(\mathrm{CH}), 127.8(\mathrm{CH}), 127.9(\mathrm{CH})$, $128.0(\mathrm{CH}), 129.7(\mathrm{CH}), 129.8(\mathrm{CH}), 134.3(\mathrm{CH}), 134.5$ (C), 134.8 (C), 136.1 (C), 151.3 (C), 168.3 (C). Anal. Calcd. for $\mathrm{C}_{18} \mathrm{H}_{17} \mathrm{NO}_{3}: \mathrm{C}, 73.22 \% ; \mathrm{H}, 5.76 \% ; \mathrm{N}, 4.75 \%$. Found: C, $73.57 \% ; \mathrm{H}, 6.01 \%$; N, $4.33 \%$.

\section{Acknowledgments}

The authors thank the Conselho Nacional de Densenvolvimento Científico e Tecnológico (CNPq) for a fellowship to SC.

\section{References}

1. Cunha, S.; Kascheres A.; J. Braz. Chem. Soc. 2001, 12, 481, and references therein.

2. Kascheres, A.; Joussef, A.C.; Duarte, H.C.; Tetrahedron Lett. 1983, 24, 1837; Hamada, A.; Takizawa, T.; Chem. Pharm. Bull. 1975, 23, 2938.; Hamada, A.; Takizawa, T.; Tetrahedron Lett. 1972, 13, 1849; Obata, N.; Takizawa, T.; Tetrahedron Lett. 1970, 11, 2231.

3. Kelly, S. E. In Comprehensive Organic Synthesis; Trost, B. M.; Fleming, I., eds.; Vol. 1; Pergamon Press: Oxford, 1991.

4. Meshram, H. M.; Reddy, G. S.; Reddy, M. M.; Yadav, J. S.; Tetrahedron Lett. 1998, 39, 4107.

5. Aitken, R. A.; Karodia, N.; Liebigs Ann. Recl. 1997, 779.

6. Aitken, R. A.; Karodia, N.; Tetrahedron 1998, 54, 9223.

7. Smith, M. B.; Organic Synthesis, McGraw-Hill, Inc.: Singapore, 1994, p. 782. 
8. Cunha, S.; Kascheres A.; J. Braz. Chem. Soc. 2000, 11, 525.

9. Kascheres, A.; Rodrigues, J. A. R.; J. Org. Chem. 1975, 40, 1440.

10. Kascheres. A.; Marchi Jr., D.; J. Org. Chem. 1975, 40, 2985.

11. Kascheres, A; Correa Filho, J.; Cunha. S.; Tetrahedron 1993, $49,381$.

12. Gösl, R.; Neuwsen, A.; Org. Synth. 1963, 43, 1.

13. Balasubramanian, A.; McIntosh, J. M.; Snieckus, V.; J. Org. Chem. 1970, 35, 433.

14. Westwood, N. B.; Walker, R. T.; Tetrahedron 1998, 54, 13391; Wyatt, P. G.; Anslow, A. S.; Coomber, B. A.; Cousins, R. P. C.; Evans,D. N.; Gilbert, V. S.; Humber, D. C.; Patermoster, I. L.; Sollins, S. L.; Tapolczay, D. J.; Weingarten, G. G.; Nucleosides Nucleotides 1995, 14, 2039.
15. Chua, S-G.; Cook, M. J.; Katritzky, A.; J. Chem. Soc., Perkin Trans. 2, 1974, 546.

16. Breslow, R.; Eicher, T.; Peterson, R. A.; Krebs, A.; Posner, J.; J. Am. Chem. Soc. 1965, 87, 1320.

17. Poyla, J. B.; Spotswood, T. M.; Rec. Trav. Chim. 1948, 67, 927.

18. Toda, F.; Mitote, T.; Akagi. K.; Bull. Chem. Soc. Jpn. 1969, 31, 1777.

Received: November 11, 2001 Published on the web: July 16, 2002

FAPESP helped in meeting the publication costs of this article. 